\title{
THE TREATY OF NICE: ARMING THE COURTS TO DEFEND A EUROPEAN BILL OF RIGHTS?
}

\author{
LIZ HEFFERNAN*
}

I

INTRODUCTION

\section{A. Background}

In December 2000, the European heads of government, meeting in Nice, took several momentous steps in the constitutional development of the European Union ("E.U."). Chief among them was the creation of a Charter of Fundamental Rights, a strikingly broad catalogue of individual rights and freedoms drawn from both the civil and political, and economic and social rights traditions. ${ }^{1}$ Consensus on the Charter's substantive guarantee was overshadowed by contention over its status in the E.U. legal order. In a compromise emblematic of European decision-making, the member states ${ }^{2}$ adopted the Charter but left open the crucial issue of enforcement. Thus, for the time being, the Charter is no more than a non-binding declaration that copperfastens the E.U.'s existing commitment to human rights, as expressed in various treaty provisions and legislative measures, ${ }^{3}$ and, above all, in the vibrant unenumerated rights tradition of the European Court of Justice. ${ }^{4}$ Potentially, the Nice Summit will mark a major milepost on the road to a European bill of rights. Assuming the member states ultimately enact remedial measures, including judicial protection, the

Copyright (C) 2002 by Liz Heffernan

This article is also available at http://www.law.duke.edu/journals/65LCPHeffernan.

* $\quad$ LL.B., Trinity College, Dublin; LL.M., Dalhousie University; LL.M. and J.S.D., University of Chicago; Barrister-at-Law, Lecturer in Law, University College, Dublin. Thanks to Conor McAuliffe, David Strauss, and Barry Sullivan for their advice and helpful comments.

1. 2000 O.J. (C 364) 1. See generally Editorial Comments, The EU Charter of Fundamental Rights Still Under Discussion, 38 Comm. MKT. L. REV. 1 (2001); Gráinne De Búrca, The Drafting of the European Union Charter of Fundamental Rights, 26 EUR. L. REV. 126 (2001).

2. The member states are: Austria, Belgium, Denmark, Finland, France, Germany, Greece, Ireland, Italy, Luxembourg, the Netherlands, Portugal, Spain, Sweden, and the United Kingdom. (2000).

3. See generally Koen Lenaerts, Fundamental Rights in the European Union, 25 EUR. L. REV. 575

4. See generally G.C. Rodriguez Iglesias, The Protection of Fundamental Rights in the Case Law of the Court of Justice of the European Communities, 1 COLUM. J. EUR. L. 169 (1995); Bruno de Witte, The Past and Future Role of the European Court of Justice in the Protection of Human Rights, in HuMAN Rights IN THE EUROPEAN UNION 859 (Philip Alston ed., 1999). 
transition may prove no less influential than the adoption of the Bill of Rights in the United States.

In the immediate term, however, the Nice Summit will be remembered for a separate order of business, namely, the latest major revision to the various instruments comprising the Constitution of the Union. ${ }^{5}$ The Treaty of Nice, ${ }^{6}$ which will enter into force following ratification by each of the member states, is designed to prepare the principal branches of government for enlargement to the east, which, according to current projections, could extend the membership from fifteen to twenty-seven states or more. In keeping with prior practice, the task of negotiating and finalizing the necessary amendments was entrusted to an intergovernmental conference ("IGC 2000") made up of representatives of the member states.

IGC 2000's central focus was reform of the political institutions, notably the Commission and the Council. ${ }^{8}$ The European Community courts were a less conspicuous but ultimately no less important item on the agenda. ${ }^{9}$ Projected changes to the judicial branch were inspired not only by the prospect of enlargement, but also by an urgent need to remedy overburdened dockets and inefficiencies in the administration of justice. In Luxembourg, the seat of the Community courts, the problem of docket control is by no means new. For several years, the Court of Justice has been waging a losing battle to keep pace

5. Principally, Treaty Establishing the European COMMUNity, Nov 10, 1997, O.J. (C 340) 3 (1997), as amended by the TREATY OF AMSTERDAM [hereinafter EC TREATY], and MAASTRICHT TREATY ON EUROPEAN UNION, 1992 O.J. (C 224) 1 (1992) [hereinafter EU TREATY].

6. Treaty of Nice AmEnding the Treaty on European Union, the Treaties Establishing THE European COMMUNities AND CERTAin RELATED ACTS, Feb. 26, 2001, O.J. (C 80) 1 (2001) [hereinafter TREATY OF NICE].

7. Originally, the scheduled date for entry into force was January 1, 2003. The Treaty, however, was rejected by Irish voters in a referendum; this outcome will possibly delay but probably not prevent its entry into force. The Irish will likely be asked to change their position in a second referendum, which will take place sometime in 2002. In the other fourteen member states, ratification is contingent on parliamentary rather than popular vote. See Editorial, Ireland's No to Europe, N.Y. TIMES, June 14, 2001, at A32; Voters in Ireland Reject Expansion of European Union, N.Y. TIMES, June 9, 2001, at A1.

8. There are four primary institutions: the Council, the Commission, the Parliament, and the Court of Justice. The Council is the Community's power base, exercising primary responsibility for policy and legislation. It is comprised of each of the member states, who are represented at the ministerial level and motivated, first and foremost, by national as opposed to Community interest. See EC TREATY arts. 202-10 (formerly arts. 145-54). The Commission is the institution most closely associated with Community interest. Comprised of twenty Commissioners, each of whom is responsible for one or more areas of Community policy, the Commission is intimately involved in virtually every aspect of Community activity. Its functions are predominantly executive but also extend to the legislative and judicial realms. See EC TREATY arts. 211-15 (formerly arts. 155-63). The Parliament has gradually grown in stature from a consultative conference of national representatives to a directly elected assembly with decision-making authority. It has significant control over the E.U. budget but lacks the direct legislative power of the U.S. Congress. See EC TREATY arts. 189-201 (formerly arts. 137-44). For a discussion of the Court of Justice, see infra Part I.B.

9. The bulk of the legal rules governing the European Union, including the judicial system, are located in the European Community Treaty, as amended. Thus, for the most part, we will speak in terms of "Community" rather than "Union." References to treaty articles are to the EC Treaty, unless otherwise stated, and to the articles as renumbered by the Treaty of Amsterdam, with the preAmsterdam numbering in parenthesis. 
with the organic growth of Community litigation. A Court of First Instance ("CFI"), created in 1989, has played its part in alleviating caseload pressures. ${ }^{10}$ The benefit of this additional Community forum has been offset by several factors: the exponential growth of Community legislation, the accession of new member states, and the extension of Community competence to fields such as the environment, intellectual property, and social policy. These days, the CFI, no less than the Court, is working at the limits of its capacity. Both courts are afflicted with burgeoning caseloads and the manifold side effects of congestion, including an increase in the length of proceedings. ${ }^{11}$ Consequently, the Treaty of Nice is not only the latest chapter in constitution-building but also the Community's most ambitious docket-control initiative.

Curiously, the E.U. institutions, national governments, and academic scholars view these reforms - the creation of a Charter of Fundamental Rights and docket-control measures for the Community courts-as two independently significant but essentially unrelated events. In fact, the Charter's prospects are intrinsically linked to the docket-control initiative, as the defense of a bill of rights rests ultimately in judicial hands, a truism demonstrated time and again by the United States Supreme Court. Assuming the E.U. Charter is armored with judicial protection, the Court of Justice will become a constitutional court in the truly populist sense of the term. The workload implications will be enormous, especially for a court struggling to meet its existing responsibilities. In Europe, as elsewhere, the administration of justice and the protection of fundamental rights are interdependent imperatives. With these thoughts in mind, this article examines the projected reforms to the Community courts contained in the Treaty of Nice. It begins with a brief overview of the European judicial system.

\section{B. The Judicial System}

The Treaty Establishing the European Community (the "EC Treaty") places in the hands of the Court of Justice responsibility for ensuring that "in the interpretation and application of this Treaty the law is observed." ${ }^{12}$ The Court sits in a multifaceted capacity: as a constitutional court, defining the balance of power between the Community and the member states and resolving conflicts between the member states inter se; as an administrative court, re-

10. See EC TREATY art. 225 (formerly art. 168a); Council Decision 88/591, establishing a Court of First Instance of the European Communities, 1988 O.J. (L 319) 1.

11. In 2000, 503 new cases were filed at the Court of Justice, 526 cases were closed, and 873 cases were pending at year end. At the CFI, 387 cases were filed, 327 closed, and 748 pending. See Extracts from the Annual Report of the Court of Justice 2000, at http://curia.eu.int/en/pei/rapan.htm.

12. EC TREATY art. 220 (formerly art. 164). See generally ANTHONY ARNULl, THE EUROPEAN UNION AND ITS COURT OF JUSTICE (1999); MARK BREARLEY \& MARK HOSKINS, REMEDIES IN E.C. LAW (2d ed. 1998); L. NeVIlle Brown \& Tom Kennedy, The Court of Justice of the European COMMUNities (5th ed. 2000); KoEn LENAERTS \& DiRK ARTS, PROCEDURAL LAW OF THE EUROPEAN UNION (Robert Bray ed., 1999); HJALTE RASMUSSEN, THE EUROPEAN COURT OF JUSTICE (1998); David O. Edwards, How the Court of Justice Works, 20 EUR. L. REV. 539 (1995); Martin Shapiro, The European Court of Justice, in THE EVOLUTION OF EUROPEAN UNION LAW 321 (Paul Craig \& Gráinne De Búrca eds., 1999). 
viewing the regulatory activities of the Community's political institutions; and as a supreme court, hearing appeals from the CFI and entertaining requests from the national courts for so-called "preliminary rulings" on the validity and interpretation of Community law. Through its various guises, the Court has played a fundamental role over the years in shepherding the development of Community law and securing uniformity in its application throughout the member states.

Although maintaining the rule of law falls chiefly on the shoulders of the Court, certain of its tasks have been assumed by the CFI. ${ }^{13}$ As its title suggests, the CFI is a trial court, and its decisions may be appealed to the Court on points of law. There are currently no other courts exclusive to the Community, except for certain specialized quasi-judicial bodies. ${ }^{14}$ In the absence of lower Community courts, akin to federal district courts and courts of appeals in the United States, individuals turn to their national courts as the natural fora for the vindication of Community rights and the adjudication of Community claims.

The Court of Justice is not a court of general jurisdiction. Its jurisdiction is derived from specific grants contained in the EC Treaty and other instruments. These provisions create a broad competence for the court, straddling functions that would be performed by a series of specialized courts in a continental European system. The caseload of the Court is as eclectic as the European Union itself. Suits wind their way to Luxembourg at the behest of many and varied actors and along diverse procedural routes. The principal grants of jurisdiction to the Court of Justice are fivefold. First, various provisions of the EC Treaty facilitate judicial review of the action or, conversely, inaction of Community government. ${ }^{15}$ Jurisdiction over these "direct actions" - cases that are filed directly in Luxembourg as opposed to in the national courts-is divided between the Court of Justice and the CFI. The Court hears actions instituted by privileged parties - a member state or Community institution-whereas the CFI hears actions instituted by private parties-individuals and corporations. Second, the Court enjoys appellate jurisdiction over CFI decisions but only as to points of law. ${ }^{16}$ Third, the Court hears and determines enforcement actions against member states for breach of Community law. ${ }^{17}$ Fourth, the Court receives references from the national courts for "preliminary rulings" on the validity and interpre-

13. See generally Timothy Millett, THE COURT OF FIRST InSTANCE OF THE EUROPEAN COMMunities (1990); Sir Christopher Bellamy, The Court of First Instance-A Day in the Life of a Judge, in I JUDICIAL REVIEW IN THE EUROPEAN UNION: LIBER AMERICORUM IN HONOUR OF LORD SLYNN OF HADLEY 81 (David O'Keefe \& Antonio Bavasso eds., 2000).

14. Notably, the Alicante Boards of Appeal established under the Community Trademark Regulation. See Council Regulation 40/94 on the Community Trademark, 1994 O.J. (L 11) 1 [hereinafter Trademark Regulation].

15. EC TREATY arts. 230, 232, 241, 235, and 288 (formerly arts. 173, 175, 184, 278, and 215).

16. EC TREATY art. 225(1) (formerly art. 168a); STATUTE OF THE COURT OF JUSTICE, Feb. 26, 2001, arts. 49-51, 2001 O.J. (c80) 53 [hereinafter STATUTE]; COURT OF JUSTICE, CODIFIED VERSIONS of Rules of Procedure of the Court of Justice, Mar. 6, 1999, arts. 110-123, 1999 O.J. (c65) 1 [hereinafter RULES].

17. EC TREATY arts. 226-28 (formerly arts. 169-71). 
tation of Community law. ${ }^{18}$ Finally, unlike the U.S. Supreme Court, the Court has at least a limited authority to issue advisory opinions. ${ }^{19}$

The jurisdiction of the Court of Justice also differs from that of the U.S. Supreme Court in that it is mandatory in all respects, a significant drawback in terms of docket control. Save for some technical wrinkle, the Court must exercise jurisdiction without regard to the persona of the individual suit or its place in the legal landscape. There is no certiorari mechanism that would enable the Court to select certain cases for adjudication and reject others. Also, whereas the lower federal courts in the United States exercise concurrent jurisdiction over most matters within the Supreme Court's original jurisdiction, the Court of Justice is designated a court of first and last resort for the resolution of all cases other than the categories of direct action expressly conferred on the CFI.

The judicial culture in Luxembourg differs from that of the U.S. Supreme Court in several other respects that bear on the present discussion. ${ }^{20}$ The composition of the Court is determined by an unwritten nationality requirementone judge per member state. This diversity is a boon and arguably even a necessity, but it comes at the price of an increase in the size of the bench with the accession of each new member state to the Union. Similarly, the working language of the Court is French, but a litigant's entitlement to have her case heard in any of eleven other languages necessitates the translation of most court documents, leading to delays at every stage of proceedings. ${ }^{21}$ Also, the practice of delivering judgments in all of the Community languages further delays their publication. The fusion of continental and common law systems accounts for other characteristics unfamiliar to the American observer. Collegiate adjudication is the hallmark of judicial practice in Luxembourg. Deliberations are held in closed chambers and result in a single collective judgment without separate opinions, whether concurring or dissenting. ${ }^{22}$ The judgment identifies the judges sitting on the case but does not reveal the way they voted, much less the reasons why. The persona of the individual justice, so much a feature of U.S. Supreme Court culture, is entirely absent. The compulsory closing of judicial ranks is said to shield individual judges from national pressure and to strengthen the Court's hand in resolving the great controversies of the day.

Collegiate decision-making on the Court is tempered somewhat by the role of the advocate general, a French inspiration. ${ }^{23}$ Each case is assigned to one of

18. EC TREATY art. 234 (formerly art. 177).

19. EC TREATY art. 30(6) (formerly art. 228(6)).

20. See generally Giuseppe Federico Mancini, Language, Culture and Politics in the Life of the European Court of Justice, 1 COLUM. J. EUR. L. 397 (1995).

21. The entitlement extends to the ten official languages (in addition to French): Danish, Dutch, English, Finnish, German, Greek, Italian, Portuguese, Spanish, Swedish, and Irish, which has a special, nonofficial status. See RULES, supra note 16, at art. 29.

22. RULES, supra note 16, at arts. 27, 63; STATUTE, supra note 16, at arts. 32-33.

23. See EC TREATY art. 222 (formerly art. 166); RULES, supra note 16, at art. 59. The office is similar to the commissaire du gouvernement in the French Conseil d'Etat. See generally Francis G. Jacobs, Advocates General and Judges in the European Court of Justice: Some Personal Reflections, in 
nine advocates general-jurists on par with the judges themselves-who engages in research and analysis independent of the parties and the Court. At the close of party submissions, the advocate general publishes an opinion on the merits which the Court is free to accept or reject in whole or in part. In style as well as in substance, the advocate general's individualism provides a welcome contrast to the Court's collectivism and, from a common law perspective, functions in much the same way as a separate opinion. Finally, while Community procedure resembles federal procedure insofar as it includes both a written and an oral stage ${ }^{24}$ to the American eye it is unusually elaborate, characterized by several cultural quirks that facilitate multinational adjudication but tend to have a detrimental effect on the efficient flow of litigation. ${ }^{25}$

Cross-cultural differences are not limited to procedural matters. For example, the approach to the interpretation of Community law, rooted in the international tradition, would be anathema to an American originalist. ${ }^{26}$ An emphasis on context and purpose over literalism and precedent has allowed the Court remarkable freedom to develop Community law over the decades, often at the expense of the member states. ${ }^{27}$ Judicial activism, however, is no less controversial than in the United States and has become increasingly difficult to defend. Through the process of intergovernmental conference and treaty amendmentnow virtually a routine feature of lawmaking in the Community-the member states have stolen the Court's thunder in resolving many of the great controversies of the day.

Supplementing the Court of Justice, the CFI was established in 1989, at a time when the Court was struggling to maintain control of its docket. Its architects had an eye toward two particular drains on judicial resources:fact-intensive cases and cases of minimal political or constitutional import. Initially, the CFI's jurisdiction was limited to specific substantive categories of direct actions-notably competition cases (antitrust) and staff cases (suits against the Community qua employer) - instituted by individuals or corporations. Its jurisdiction has since been extended to embrace all direct actions so filed. ${ }^{28}$ Relatively restric-

JUdiCIAL REVIEW IN EUROPEAN UNION LAW: LIBER AMERICORUM IN HONOUR OF LORD SLYNN OF HADlEY 17 (David O'Keefe \& Antonio Bavasso eds., 2000); Takis Tridimas, The Role of the Advocate General in the Development of Community Law, 348 COMM. MKT. L. REV. 1349 (1997). The Court appoints a First Advocate General for a term of one year with responsibility for assigning cases among the advocates general. RULES, supra note 16, at art. 10.

24. See STATUTE, supra note 16, at art. 18.

25. For example, a judge, assigned by the Court as a rapporteur, issues a preliminary report on procedural matters and a second report on the merits, prior to oral argument. RULES, supra note 17, at arts. 9(2) and 44. In addition, the Court may conduct independent fact-finding, separate and distinct from the adversarial process. RULES, supra note 16, at art. 45-52.

26. See, e.g., Case C-283/81, CILFIT v. Italian Ministry of Health, 1982 E.C.R. 3415, 3430 ("Every provision of Community law must be placed in its context and interpreted in the light of the provisions of Community law as a whole, regard being had to the objectives thereof and to its state of evolution at the date on which the provision in question is to be applied.").

27. Perhaps the most dynamic doctrinal development was the creation of an unenumerated code of fundamental Community rights. See Iglesias, supra note 4, at 170.

28. See Bellamy, supra note 13 , at 82 . 
tive rules on standing render this jurisdiction less generous than it sounds. A private litigant must show that she is individually and directly affected by the government action in question, a difficult threshold to cross in the Community context. $^{29}$ The issue of standing is one fragment of a broader controversy regarding individual access to the Community courts for the vindication of Community rights. ${ }^{30}$ As we shall see, however, it is an issue that was sadly neglected at IGC 2000. As currently drafted, the EC Treaty precludes conferring on the CFI jurisdiction over preliminary references, enforcement actions, or advisory opinions. $^{31}$

The relationship between the Court of Justice and the national courts is central to an understanding of the European system but is as difficult to sketch as the interaction between federal and state courts in the United States. The national courts are the natural fora for all claims not expressly assigned to the Court or the CFI. They are obliged to apply Community law, which is supreme over national law, and, where appropriate, to accord it "direct effect" within the national systems. ${ }^{32}$ The national courts must afford individuals full and effective protection of Community rights, including reparation. ${ }^{33}$

Concerned about the fate of Community law in the hands of national judges, the signatories to the EC Treaty reserved to the Court of Justice the final say on the content and meaning of Community law. Unlike state and lower federal courts in the United States, the national courts lack the power to annul Community acts. ${ }^{34}$ When an issue of Community law arises in a national proceeding, the national court seeks the guidance of the Court of Justice through the preliminary reference procedure. Under Article 234 (formerly Article 177), a lower national court may refer a case to Luxembourg where it considers that a

29. See Case C-73/97 P, France v. Comafrica and Others, 1999 E.C.R. I-185 (overturning the CFI's holding that traders had standing to challenge a Commission regulation on determining the quantities of bananas that the traders were entitled to import into the Community in 1994); see also Anthony Arnull, Private Applicants and the Action for Annulment Since Codorniu, 38 COMM. MKT. L. REV. 7, 51 (2001) (arguing that the Court lacks a coherent overall policy on standing and admissibility, a consequence that reflects its preoccupation with workload).

30. See Carol Harlow, Towards a Theory of Access for the European Court of Justice, 12 YBK. EUR. L. 213 (1992); Angela Ward, Amsterdam and Amendment to Article 230: An Opportunity Lost or Simply Deferred?, in THE Future of THE JUdicial SYSTEM OF THE E.U. 37 (Alan Dashwood \& Angus Johnson eds., 2001).

31. EC TREATY art. 225 (formerly art. 168a), arts. 226-27 (formerly arts. 169-70), and art. 300(6) (formerly art. 228(6)).

32. The self-executing potential of Community law varies depending on the nature of the legal instrument in question. See generally EC TREATY art. 249 (formerly art. 189). See, e.g., Case C-26/62, Van Gend en Loos, 1963 E.C.R. 3; Case C-41/74, Van Duyn 1974 E.C.R. 1337; Joined Cases C-6/90 \& C-9/90, Francovich, 1991 E.C.R. I-5357.

33. See, e.g., Joined Cases C-46/93 \& C-48/93, Factortame, 1996 E.C.R. I-1029. See generally Walter Van Guerven, Of Rights, Remedies and Procedures, 37 COMM. MKT. L. REV. 501 (2000).

34. Community acts are presumed to be valid until set aside by the Court of Justice. See EC TREATY art. 231 (formerly art. 174). Thus, even in a case of patent invalidity, a national court is powerless to terminate or suspend the operation of a Community act within its national territory. See Case C-314/85, Foto-Frost, 1987 E.C.R. 4199. The only recourse for the national court is to refer the to the Court of Justice for a ruling on the validity of the act in question. 
ruling on a question of Community law is necessary to enable it to decide a case. Faced with the same circumstance, a national court of last resort must refer the case. ${ }^{35}$ It is the task of the Court of Justice to deliver a definitive ruling on the question or questions referred and the function of the national court to apply that ruling in order to decide the case. Thus, the system is dualist insofar as the Court of Justice lacks the power to strike down an offending national law or overturn a national judgment, an important distinction from the U.S. system.

In terms of form, the preliminary reference procedure resembles certification, as practiced in the United States,${ }^{36}$ but, as a matter of substance, it is considerably more significant. It is more than simply a means of assisting national courts in resolving issues of Community law, although it does perform that important function. Whereas the relevance of certification is undercut by the $\mathrm{Su}-$ preme Court's vibrant appellate jurisdiction, there is no system of appeals from the national supreme courts to the Court of Justice. The preliminary reference procedure is the sole mechanism whereby the Court can supervise adjudication by the national courts so as to ensure the uniform application of Community law throughout the member states. ${ }^{37}$ Not surprisingly, the bulk of the Court's docket is comprised of requests for preliminary rulings. This procedure is the foundation of the E.U. judicial edifice and, to date, neither the Court of Justice nor the member states have been willing to countenance any dramatic departures from existing practice. Thus, the real conundrum facing IGC 2000 was how to unravel the mystique of the preliminary reference.

\section{The Road to Nice}

There are several drawbacks to the intergovernmental conference as a vehicle for reform of the judicial branch. As its title suggests, the process is akin to international treaty-making. Participation is limited to member states, and issues are tabled and ultimately decided through barter and compromise among the national delegations. The mood is "make or break": The participants must broker a deal within a designated time frame or live with the status quo. The proceedings are less open and transparent than national parliamentary proceedings and certainly lack the democratic credentials associated with amending the U.S. Constitution. ${ }^{38}$ The intergovernmental conference is, quintessentially, a political thicket.

35. A modified version of the procedure governs the justice and home affairs provisions of the EC and EU Treaties. See EC TREATY art. 68 (formerly art. 73p); EU TREATY art. 35.

36. See, e.g., 28 U.S.C. $\S 1254$.

37. The Court of Justice has described its relationship with the national courts as one of cooperation and coordination. See, e.g., Case C-283/81, CILFIT, 1987 E.C.R. 4199. It has been more aptly described as one characterized by "supremacist supervision" on the part of the Court. Thomas de la Mare, Article 177 in Social and Political Context, in THE Evolution of EU LAw 215, 231 (Paul Craig \& Gráinne De Búrca eds., 1999).

38. Negotiations are conducted in closed sessions from which the media are excluded. The public receives its coverage from media reports based on official statements, press releases, and interviews af- 
IGC 2000 followed a tradition among the member states of prioritizing reform of the political institutions over reform of the courts. Initially, its mandate was limited to the so-called "Amsterdam leftovers" (that is, those issues of institutional reform left unresolved by the Treaty of Amsterdam, the last major treaty revision ${ }^{39}$ ), notably the size of the Commission and the current voting system in the Council. Eventually, judicial reform was added to the miscellany of secondary items to be addressed at IGC 2000, but only after the judiciary publicized the issue, both officially ${ }^{40}$ and extra-judicially. ${ }^{41}$ Nevertheless, throughout the Conference, the future of the Community courts was overshadowed by debate over the fate of the Commission and Council. Given the sum of tasks to be completed, the Conference was neither able nor disposed to give reform of the judicial system the attention it deserved. ${ }^{42}$

The sources on which the Conference relied in deciding the future of the Community courts were also limited. Reforming the judicial system had been the subject of low-key debate in academic and practicing circles for several years, ${ }^{43}$ but debate at IGC 2000 focused principally on the submissions of the Community Courts, ${ }^{44}$ the Commission, ${ }^{45}$ and individual member states. ${ }^{46}$ The

ter the fact. The advent of the Internet has improved accessibility: An official IGC 2000 website posted fact sheets, progress reports and conference documents. See http://europa.eu.int/comm/archives/ igc2000. Both official and media coverage are short on details and critical analysis.

39. See EC TREATY, supra note 5.

40. See Court of Justice And Court of First Instance, The Future of the Judicial SYSTEM OF THE EUROPEAN UNION (PROPOSALS AND REFLECTIONS) (1999), http://curia.eu.int/en/ txts/intergov/index/htm [hereinafter COURTS' DISCUSSION PAPER]. The President of the Court of Justice, Judge Rodriguez Iglesias, took the unprecedented step of airing his concerns in the press. See Statement of the President of the Court of Justice, The EC Court of Justice and Institutional Reform of the European Union (April 2000), http://curia.eu.int/en/txts/intergov/index.htm.

41. See, e.g., John Cooke, European Judicial Architecture: Back to the Drawing Board, 5 BAR REV. 14 (Dublin) (1999).

42. See Xenophon A. Yataganas, The Treaty of Nice: The Sharing of Power and the Institutional BALANCE In the European UniOn-A CONTINENTAL PERsPective (Harvard Law School, Jean Monet, Working Paper No. 1/01), http://www.jeanmonnetprogram.org/papers/ papers01.html (noting that reform of the courts was one of the less controversial chapters in the negotiations and that agreement was reached relatively quickly).

43. See generally BRITISH INSTITUTE OF INTERNATIONAL AND COMPARATIVE LAW, THE ROLE AND Future of THE European COURT OF JustiCE ("Slynn REPORT") (1996); Anthony Arnull, Judicial Architecture or Judicial Folly?: The Challenge Facing the European Union, 24 EUR. L. REV. 516 (1999); Jean Paul Jacques \& Joseph H.H. Weiler, On the Road to European Union-A New Judicial Architecture: An Agenda for the Intergovernmental Conference, 27 COMM. MкT. L. REV. 185 (1996); David W. Scorey, A New Model for the Communities' Judicial Architecture in the New Union, 21 EUR. L. REV. 224 (1996); Walter Van Guerven, The Role and Structure of the European Judiciary Now and in the Future, 21 EUR. L. REV. 211 (1996). For a more recent discussion of reform in the context of IGC 2000, see generally Cathryn Costello, Preliminary Reference Procedure and the 2000 Intergovernmental Conference, 21 DuB. UnIV. L.J. 40 (1999); Angus Johnson, Judicial Reform and the Treaty of Nice, 38 ComM. MKT. L. REV. 499 (2001); Hjalte Rasmussen, Remedying the Crumbling EC Judicial System, 37 Comm. MKT. L. REV. 1071 (2000); Catherine Turner \& Rodolphe Muñoz, Revising the Judicial Architecture of the European Union, 19 YBK. EUR. L. 1 (1999-2000).

44. Namely, the CONTRIBUTION BY THE COURT OF JUSTICE AND THE COURT OF FIRST INSTANCE TO THE INTERGOVERNMENTAL CONFERENCE (2000), and the COURTS' DisCUSSION PAPER, supra note 40. 
European Bar was also represented in the guise of a report by the Council of the Bars and Law Societies of the European Union ("CCBE"), which shed some welcome light on the perspective of the litigant and practitioner. ${ }^{47}$ Apparently, the Conference did not consider less conventional sources, such as the opinions of nongovernmental organizations, interest groups, or academics. In other words, the Conference did not approach reform from a tabula rasa but rather considered only somewhat conservative ideas drawn from conventional sources. $^{48}$

Certain official reports proved particularly influential in shaping the reforms ultimately adopted, as well as those rejected, at Nice. The Court of Justice and the Court of First Instance published their views on the dilemma in a May 1999 paper on the future of the judicial system. ${ }^{49}$ The Courts' paper was cast as a springboard for debate: The tone was reflective rather than directive, as the Courts discussed the pros and cons of various reforms without endorsing any one, much less presenting a vision of where they saw themselves in ten or twenty years. The Commission took up the reins by setting up an independent working party under the chairmanship of the former president of the Court of Justice, Ole Due. The Due Report, ${ }^{50}$ published in January 2000, contained a more comprehensive and rigorous analysis but, ultimately, settled for a relatively conservative approach to reform. Finally, the Friends of the Presidency Group, consisting of legal experts from the member states and Community institutions, was more intimately involved in IGC 2000, monitoring the negotiations, submitting draft texts, and hammering out compromise formulae..$^{51}$

Influenced perhaps by the cautious tenor of the Courts and the Commission's Working Party, the Conference eschewed radical reform. Thus, a dramatic overhaul of the judicial system was rejected virtually from the outset. The

45. See, e.g., EUROPEAN COMMISSION, REPORT BY THE WORKING PARTY ON THE FUTURE OF THE EUROPEAN COMMUNITIES' COURT SYSTEM (2000), http://europa.eu.int/comm/dgs/legal_service/ docs/due_en.pdf [hereinafter DUE REPORT]; Intergovernmental Conference: Commission Presents Additional Contribution on Reform of the Community Courts, IP/00/213 (Mar. 1, 2000), http://europa.eu.init/comm/archives/igc2000/offdocs/index_en.htm\#contributions.

46. See, e.g., IGC 2000: Contribution from the French Delegation on Reform of the Judicial System of the European Union, CONFER 4726/00 (Mar. 27, 2000) [hereinafter CONTRIBUTION FROM THE FRENCH DELEGATION].

47. Contribution from the CCBE for the Intergovernmental Conference, CONFER/VAR 3966 (May $18,2000)$ [hereinafter Contribution from the CCBE].

48. Other than the submissions of the CCBE, the only documents listed on the IGC 2000 website and, therefore, presumably considered, were the Courts' Discussion Paper and subsequent contributions, the Due Report, and submissions from other Community institutions and the individual member states. See http://europa.eu.int/comm/archives/igc2000.

49. COURTS' DISCUSSION PAPER, supra note 40.

50. DUE REPORT, supra note 45.

51. See, e.g., Friends of the Presidency Group (Court of Justice and Court of First Instance), IGC 2000: Proceedings and Amendments to be Made with Regard to the Court of Justice and the Court of First Instance, CONFER 4747/00 (May 31, 2000); Friends of the Presidency Group (Court of Justice and Court of First Instance), IGC 2000: Interim Report on Amendments to be Made to the Treaties with Regard to the Court of Justice and the Court of First Instance, CONFER 4729/00 (Mar. 31, 2000) [hereinafter Friends of the Presidency Interim Report]. 
reticence of the Conference to grasp the proverbial nettle is also explained in part by the procedural labyrinth of reform methodology. At issue for the Conference was not only the nature and extent of reform but also the means and the timing. Should the Conference redesign the system or maintain the current structure? Should it adopt any one or a combination of various proposed changes? Should the Conference decide these issues or delegate decisionmaking to the Council? And, should these decisions be taken now or postponed until the next intergovernmental conference? Given the backdrop to IGC 2000, coupled with a European propensity to "wait and see," it is not altogether surprising that the Conference chose the least adventurous answers to these questions. At the end of the day, the Conference opted to renovate rather than redesign the judicial architecture and, at the same time, to make the system more adaptable to change in the future. Thus, it adopted some proposals, rejected others, left to the Council the resolution of many of the details, and declared the debate ongoing.

II

TREATY OF NICE

\section{A. Flexibility}

The role and operation of the Community courts is set out in the EC Treaty, the Statute of the Court of Justice (which is contained in a separate protocol to the Treaty), and the Rules of Procedure. The division of labor among the three reflects a certain hierarchy, not unlike regulation of the U.S. courts under the Constitution, federal statutes, and federal rules of procedure. The European judicial code, however, is considerably more rigid. Many of the details surrounding the day-to-day operation of the Community courts, which could safely be housed in the Rules, are set out in the two primary sources. So located, these provisions can be amended only through the cumbersome process of treaty amendment. Amendment of the Rules is more straightforward, but only in relative terms; changes in the Rules require the unanimous approval of the Council.

The Treaty of Nice reorganizes these legal instruments in a sensible bid to rationalize the judicial code. First, certain provisions will be transferred from the Statute to the Rules, and vice versa, to ensure a proper hierarchy among the various provisions. Second, the method of amending the Statute and the Rules will be modified to facilitate future changes to the judicial code.

Of these developments, the second is the more important. Henceforth, the Council will be empowered to amend all parts of the Statute, except for Title 1, which deals with the appointment and replacement of judges and advocates general. This will enable the Community to make substantial changes to the judicial system without recourse to treaty amendment. The Conference was less generous with respect to the Rules. The Council will continue to have the final 
say over amendments, although its approval will be based on a qualified majority vote rather than unanimity. ${ }^{52}$

The failure to confer autonomy over their rules on the Community courts is a setback, inspired by an overabundance of caution. ${ }^{53}$ It is a power that the U.S. Supreme Court and the European Court of Human Rights take for granted. To an extent, the Courts have themselves to blame, having endorsed the "qualified majority vote option" as a fallback position. ${ }^{54}$ The underlying premise-that the member states have reason to fear relinquishing control over the Rules-is difficult to defend, particularly since the Treaty of Nice also provides for the transfer from the Rules to the Statute of certain matters of special concern to the member states. ${ }^{55}$ The problem with this arrangment is not that the Council is likely to stand in the way of change (particularly when acting by qualified majority), but that Council approval is precisely the kind of bureaucratic obstacle which the system can do without. Given the eclecticism of Community jurisdiction, it is in the Rules that flexibility is needed most.

These changes to the judicial code are more than a housekeeping exercise. The "flexibility" promised by the Treaty of Nice is also a neat shorthand for the Conference's reform philosophy. Whether by accident or design, the Conference made a fundamental choice to forego a major overhaul of the system in favor of ongoing, piecemeal reform. The changes crafted at Nice are not offered as an end in themselves: Some provisions will have immediate effect, whereas others will be defined only in practice. Still other issues have been left aside for another day. Collectively, these measures are intended as a first, but by no means insubstantial, step in the process of reform.

B. Composition of the Courts

1. The Court of Justice. One possible and often-touted solution to the growing caseload of the Courts is to appoint additional judges. Too many judges, however, could lead to a judicial circus and undermine confidence in the administration of justice, particularly at the Court of Justice. As the Court warned at the last enlargement of the Union, an increase in its current member-

52. Increasingly, the Council makes decisions by qualified majority, as opposed to simple majority or unanimity, in accordance with a numerical formula set out in EC TREATY art. 205(2) (formerly art. $148(2))$.

53. Some delegations were in favor of the change (or at least did not come out against it). See, e.g., Contribution from the Dutch Government-An Agenda for Internal Reforms in the European Union, CONFER 4720/00 (Mar. 6, 2000) [hereinafter Contribution from the Dutch Government]; Information Note from the Italian Delegation, 2000 IGC: Italy's Position, CONFER 4717/00 (Mar. 3, 2000). The majority of the delegations expressed considerable reservations about giving the courts the power to amend their rules. See Friends of the Presidency Interim Report, supra note 51, at 3.

54. See COURTS' DISCUSSION PAPER, supra note 40, at 14.

55. For example, provisions guaranteeing equality in the use of national languages before the Community courts transfer the issue to the Statute. 
ship of fifteen ${ }^{56}$ could transform the plenary session from a collegiate court to a deliberative assembly, while extensive recourse to decision-making by chambers could pose a threat to the consistency of Community law. ${ }^{57}$ In fact, the problem is not merely one of numbers. The composition of the Court is defined by an unwritten nationality requirement. One judge per member state has always been the convention, subject to the need for an uneven number of judges for purposes of decision. ${ }^{58}$ The practice ensures a measure of familiarity within the Community judiciary with the various national legal cultures and languages. It also necessitates an increase in the size of the bench with each new accession. With the prospect of enlarging the union to twenty or even thirty member states, the possibility of abandoning the nationality requirement-in favor, for example, of a system of rotational appointments-has been mooted. But it remains a convention that the member states are anxious to retain.

The issue of national representation in Community government is uniquely delicate and dominated negotiations on reform of each of the Community institutions under discussion at IGC 2000. In deciding the future size of the Commission, the Conference settled on a compromise solution: maintain the practice of one commissioner per member state but restructure the institution so as to limit decision-making by the whole. The Conference applied the same model to the Community courts. The new version of Article 221 entrenches the principle that the Court of Justice shall consist of "one judge per Member State" but tempers the effect by providing that the Court shall sit in chambers and, only exceptionally, in plenary session. Thus, as between the seemingly irreconcilable demands of operational efficacy and national representation, IGC 2000 came down squarely on the side of the member states. ${ }^{59}$

It is doubtful that the Conference was wise to maintain and even entrench the nationality requirement at the Court of Justice. Putting aside the propriety of this model for the Commission, what makes sense for a political institution does not necessarily function well for a court. The administration of justice has its own special concerns, such as the quality and impartiality of judicial adjudi-

56. EC TREATY art. 223 (formerly art. 167) (stipulating that the Court shall consist of fifteen judges, suitably qualified). The judges choose a president from among themselves for a three-year term.

57. Report of the COURT OF Justice on CERTAin Aspects of the APplication of the TREATY ON EUROPEAN UNION 16 (May 1995), http://europa.eu.int/en/agenda/ige-home/en-doc/justice /g-rep.html.

58. For example, prior to the accession of Austria, Finland, and Sweden in 1995, an additional judge from one of the five larger member states was appointed to ensure a bench of thirteen members. The process of appointing judges is more informal than the appointment of federal judges in the United States. Each national government has virtually unfettered discretion in nominating its candidate, and there is no independent oversight in the manner of Senate confirmation. Whereas federal judges enjoy life tenure, however, the members of the Court are appointed for six-year renewable terms. See EC TREATY art. 223 (formerly art. 167); TREVOR C. HARTLEY, THE Foundations OF EUROPEAN COMMUNITY LAW 52-54 (4th ed. 1998); Costello, supra note 43, at 45.

59. All but a couple of delegations were unwilling to relinquish the nationality requirement. See Friends of the Presidency Interim Report, supra note 51, at 10. 
cation, which place a higher premium on size than national interest. The limit of nine justices on the U.S. Supreme Court reflects such thinking. The benefit of a full panoply of nationalities must be balanced against the cost in terms of reducing functional capacity and undermining jurisprudential integrity. As a practical matter, the significance of one judge per member state is probably more symbolic than real. When the Court sits in chambers, which it increasingly does, the participation of a judge from a particular jurisdiction is not guaranteed. Nor should it matter whether a particular member state has judicial representation on a case; the judges should be objective and impartial. In addition, the national expertise that a judge brings to the Court, though beneficial, is hardly decisive. The Court has repeatedly stressed that it is not in the business of deciding national law-the preliminary reference procedure is premised on a neat distinction between national and Community law and competence. Additionally, there are means other than judicial appointments to enhance institutional familiarity with the various national systems, such as through the role of support staff, particularly in the field of legal research. From the perspective of the private litigant and of the public at large, the issue of language-conducting legal proceedings and publishing judgments in the various Community languages - is almost certainly more important than actual national representation on the Court itself. These sentiments neither negate the importance of symbolism in the Community context nor belittle diversity as a virtue in the judicial scheme. Whatever its size, the membership of the Court should reflect the diversity of the Community, in nationality as well as in other terms. The integrity of the Court, however, also rests on other virtues, such as collective deliberation, even-handed adjudication, and reasoned jurisprudence.

At the very least, the Conference could have settled on a compromise-including the advocates general in the distribution of judicial posts at the Court of Justice. Currently, advocates general are appointed through a separate process, which is in turn conditioned by national representation. Five of the nine advocates general are nominated by the five largest member states, ${ }^{60}$ while the remainder are drawn from the other member states on a rotational basis. ${ }^{61}$ The role and statute of the office is such that the periodic substitution of an advocate general for a judge should not be a bitter pill for the member states to swallow, ${ }^{62}$ and it would certainly help solve the problem of the increased caseload. The current arrangement-fifteen judges and nine advocatesgeneral-could accommodate a membership of twenty-three states. Despite the pragmatism of this idea, it never got off the ground at IGC 2000. For the larger member states, it would involve forsaking a double entitlement-to both a

60. See HARTLEY, supra note 58, at 54. The five largest member states are France, Germany, Italy, Spain, and the United Kingdom.

61. The five advocates general from the largest member states are appointed for a renewable sixyear term, whereas the other three posts are tenable for one term only. See Jacobs, supra note 23, at 28.

62. Advocates general are generally regarded as "members" of the Court, even though they lack ultimate decision-making authority. See Jacobs, supra note 23, at 18. 
judge and an advocate general-in favor of just one or the other. For most of the smaller member states, any diminution in the current level of national representation would raise the specter of marginalization within the Community, whether real or imagined. Against this backdrop, it comes as no surprise that the member states, convened as IGC 2000, opted to endorse the status quo.

Over the years, the structure of the Court has been modified to accommodate an extended bench. Currently, the Court sits as a grand plenum of fifteen judges, as a petit plenum of nine or eleven judges, or as a chamber of five or three judges. Adjudication in petit plenum and chambers has increased with the workload, and it is fast becoming the norm. Grand plenum is reserved only for the most exceptional cases. ${ }^{63}$

To allay concerns about the Court's functional cohesion, the Conference established a new structure designed to accommodate a uniquely large and potentially unwieldy bench. An incidental effect is that the Court will no longer determine its own structure, although obviously the judges will determine how cases are assigned among its various formations. Under the new arrangement, the Court will sit in chambers of three and five judges, in a new Grand Chamber of eleven, and in plenary session. ${ }^{64}$ This is not a tremendous leap from the current structure, but it involves two important modifications.

First, the Grand Chamber will serve as the storm center in the new arrangement, handling cases currently heard in petit and grand plenum. Whereas privileged parties - a member state or Community institution-will no longer have automatic access to the full court, they will be entitled to have their cases heard by the Grand Chamber. If the real judicial power is wielded in the Grand Chamber, we can expect that its composition will prove controversial. The Conference may have sensed as much. Whereas under the current practice the petit plenum is constituted on an informal, ad hoc basis, the membership of the Grand Chamber is defined in the Statute. Presided over by the President of the Court, it will consist of the presidents of the chambers of five judges (there are currently two such chambers) and other judges appointed under conditions laid down in the Rules; as such, it will function with a quorum of nine. ${ }^{65}$ Both the President of the Court and the presidents of the five-judge chambers will hold their offices for three-year renewable terms and, aside from their tenure on the Grand Chamber, will carry out important tasks within their respective spheres of influence. Thus, there is a danger that the new arrangement will create a sense of judicial hierarchy at the Court.

The second significant development is that the plenary session will become very much the exception. The new version of the Statute provides that the Court will sit as a "full court" in certain specified proceedings or where, after

63. A member state or Community institution that is a party to the proceedings enjoys the right to a plenary hearing. EC TREATY art. 221 (formerly art. 165); RULES, supra note 16, at 95(1).

64. StATUTE, supra note 16, as amended by the TREATY OF NICE, supra note 6, art. 16.

65. Id. at arts. $16 \& 17$. 
hearing the views of the advocate general, the Court considers that a case is "of exceptional importance." ${ }^{\prime 66}$ Precisely how the full court will function is an open question. A packed plenary session is curiously at odds with the Court's valued tradition of collegiate decision-making. At the same time, adjudication of these exceptional cases by a number less than the full complement may raise doubts about the unity of the bench and the equality of national representation. Looking at the overall structure, a more serious concern is whether the Court, sitting in its various satellite formations, will be able to maintain the jurisprudential integrity that is central to its constitutional mandate.

2. The CFI. The new structure of the CFI proved a good deal less controversial. The Conference recognized that increasing its membership is a less risky proposition, not least because any threat to the consistency of Community law can be tackled on appeal by the Court of Justice. Thus, the new Article 224 provides that the CFI shall comprise "at least one judge per Member State." Given the CFI's expanded role under the Treaty of Nice, a larger bench will be essential. ${ }^{67}$ The Council has given the nod to an increase of six judges on the CFI, although a system for rotating the additional appointments among the member states has yet to be settled. Provisions are also made for the CFI to sit in various formations, in accordance with its Rules of Procedure: in chambers of three and five judges, in a Grand Chamber, as a full court, and as a single judge. ${ }^{68}$

For now, practice at the CFI is likely to continue much as before. Over time, the CFI will grow within its current structure, no doubt continuing the trend in favor of adjudication by chambers or a single judge. Nevertheless, its development should be structured and carefully supervised to ensure unity and cohesion in its development of Community law. The time is ripe for a thorough review of its operational capacity and working practices. The increase in the CFI's labor and responsibility warrants a corresponding increase in financial and administrative resources. More fundamental, however, is the question of how the CFI should structure and equip itself to meet the demands of its extended mandate.

One possible structural change would involve the creation of specialized chambers. The specialization could be based on the CFI's current docket and include, for example, the field of competition. Specialized chambers could also correspond to the CFI's prospective appellate jurisdiction over judicial panels, for example, in the area of intellectual property. ${ }^{69}$ The judges themselves would not be specialists but rather would serve rotations on specialist panels. Specialized panels could be useful if they are confined to a limited number of select ar-

66. Id. at art. 16 .

67. This seems to have been the popular view among the delegations at IGC 2000. See Friends of the Presidency Interim Report, supra note 51, at 198.

68. See STATUTE, supra note 16, as amended by the TREATY OF NICE, supra note 6, art. 50.

69. See DUE REPORT, supra note 45, at 116. 
eas, such as staff cases and trademark cases. It would be vital to ensure that the concept did not presage strict subject-matter categorization. Like federal claims in the U.S., Community causes of action are not premised on neat subjectmatter distinctions. The CFI should remain a court of general jurisdiction and not a mere collection of specialized tribunals. Another interesting idea is a shift of emphasis in favor of settlement. ${ }^{70}$ The small but increasing number of cases that are settled prior to a decision being rendered hints at the potentially beneficial role that mediation could play in proceedings before the CFI. The prospective judicial panel for staff cases could be fertile ground for experimentation. At a general level, the practice of settling federal court cases in the United States might provide some helpful guidance.

3. Advocates General. The Conference sensibly resisted calls to reduce or even eliminate the role of the advocate general at the Court of Justice. ${ }^{71}$ As we have seen, the advocate general's opinion can, and generally does, exert a beneficial influence on deliberation at the Court and on the accessibility of its jurisprudence. Occasionally, however, it can be redundant, for example, where proceedings are uncontested or relatively straightforward. In such instances, resources are needlessly expended and proceedings unjustifiably lengthened. The Treaty of Nice remedies this state of affairs by introducing an element of discretion. Under the new version of Article 223, the advocate general will issue an opinion only on cases which "require his involvement." Whether the involvement of an advocate general is required will be a matter for the Court rather than the advocate general herself to determine, and will turn on whether the case raises some new point of law. Relieved of the duty to opine purely as a matter of form, the advocates general should be free to concentrate on the more complex cases, where their contribution is needed most.

Finally, under the new version of Article 224, the Council may, at some future time, make provision in the Statute for the CFI to be assisted by advocates general. The CFI has rarely utilized its existing power to appoint one of its own to perform the function ad hoc in a particular case. Given the CFI's essential trial function, the formal appointment of advocates general seems neither necessary nor desirable.

70. See generally Arjen W.H. Meij, Guest Editorial: Architects or Judges? Some Comments in Relation to the Current Debate, 37 COMM. MKT. L. REV. 1039, 1042 (2000) (lamenting that recent developments in the field of mediation and alternative dispute resolution have escaped the reform debate); Soren J. Schonberg, Coping with Judicial Over-Load: The Role of Mediation and Settlement in Community Court Litigation, 38 COMM. MKT. L. REV. 333 (2001) (arguing in favor of formal accommodation of settlement techniques in the rules of procedure of the Court and the CFI).

71. The number of advocates general will remain unchanged and may even be increased by unanimous vote of the Council at the request of the Court. See EC TREATY art. 222 (formerly art. 166). 


\section{Direct Actions}

1. Extending the Jurisdiction of the CFI. The jurisdiction of the CFI over direct actions has increased gradually over the years. Initially, the CFI was given with jurisdiction over a limited number of categories of direct actions brought by natural or legal persons, principally in the fields of Community employment and competition. Its jurisdiction was subsequently extended to cover all actions brought by natural or legal persons. Thus, at the current time, the CFI hears actions brought by private parties (individuals or corporations), and the Court of Justice hears actions instituted by privileged parties (member states or Community institutions).

The new version of Article 225 states that the CFI will have jurisdiction over most classes of direct actions, "with the exception of those assigned to a judicial panel and those reserved in the Statute for the Court of Justice." Although it falls short of declaring the CFI the first or primary judicial forum for all direct actions, Article 225 embodies an important change in emphasis: trial and adjudication by the CFI will become the rule rather than the exception. This is a natural and desirable development. As the legal system matures, it is appropriate that the CFI and the Court pursue their respective vocations, the former as a general trial court and the latter as an appellate supreme court.

What does this mean in practical terms? The Treaty of Nice changes nothing in itself; the details will be thrashed out in the Council and implemented by amendment to the Statute. Thus, this important reform is sketched only in principle by the Treaty. In a declaration attached to the Treaty, the Conference calls upon the Court of Justice and the Commission to consider the division of competence between the two courts and to tender proposals when the Treaty enters into force. ${ }^{72}$ A meaningful improvement in working conditions at the Court will require a marked decrease in its responsibilities over direct actions. When CFI's jurisdiction is broadened, the change will affect its personal, as opposed to subject matter, jurisdiction. In other words, the CFI will continue to hear the same categories of cases, but its competence will then extend to at least some of the suits involving privileged parties now heard by the Court of Justice. How much of this extended jurisdiction-direct actions involving privileged parties-will be left to the Court is unclear.

72. See Declaration on Article 225(2) and (3) of the Treaty Establishing the European Community, 2001 O.J. (C 80) 79 [hereinafter Declaration on Article 225]. The issue is not addressed in any detail in the reports of the Friends of the Presidency Interim Report, supra note 51. 
2. Defining the Court of Justice's Residual Jurisdiction. Direct access to the Court of Justice, if permitted at all, should be based on two independent criteria: the importance of the case and the need for speedy resolution. While defining jurisdiction based on the need for speedy resolution is feasible, using a benchmark as elusive as "importance" seems a hopeless quest.

Direct actions take two significant forms: proceedings for judicial review of the legality of Community acts and actions for compensation. Traditionally, the Court of Justice alone was authorized to review Community acts, including Community legislation. Whereas judicial review proceedings are generally deemed "important," they are also ubiquitous, and the Court of Justice now shares the burden of this jurisdiction with the CFI. As between the two courts, it seems impossible to assign judicial review proceedings on the basis of general classifications relating to the importance of the impugned legislation. In the course of deciding direct actions brought by individuals and corporations, the CFI may be called upon to pass on the legality of legislation, both general and specific. Typically, the CFI alone reviews legislation that is limited in scopethe classic example is a Commission decision directed to one or more corporations in the field of competition. The converse, however, does not hold true. Whereas direct actions at the Court of Justice invariably involve general legislation, these measures are also currently challenged in proceedings before the CFI. Consequently, while in theory we could conjure a division of labor between the Court and the CFI based on the normative value of the various forms of legislation, in reality the Community's legislative structure is not patterned on a normative distinction. Nor does the shorthand reference to general and specific legislation capture the distinction; normative issues surface across the board.

The current regime invokes an alternative indicator of importance, namely, the identity of the parties. Actions brought by private parties (individuals or corporations) go to the CFI, whereas actions brought by privileged parties (member states or Community institutions) go to the Court. Party labels provide an easy means of assigning cases to the CFI, but, standing alone, they are a poor barometer of the need for direct access to the Court. Litigation involving the member states and Community institutions often raises serious constitutional questions, but not routinely so. Conversely, those same questions may surface in litigation before the CFI. A further vagary of the current division is the possibility of simultaneous challenges, in both the CFI and the Court, at the behest of private and privileged litigants, respectively.

These considerations underscore the wisdom of vesting original jurisdiction in the CFI and appellate jurisdiction in the Court. There is no good reason why the CFI should not become the first judicial forum for direct actions. Any doubts about its ability to hear and determine proceedings for judicial review should be assuaged by its proven record. The time is ripe for the privileged par- 
ties to relinquish automatic access to the Court in exchange for a more robust system overall. ${ }^{73}$ After all, ultimate supervision by the Court is safeguarded by the possibility of appeals on points of law. Private and privileged parties alike stand to benefit from the judicial deliberations necessitated by an additional tier of review. Certainly, the value of proceedings before the U.S. Supreme Court is enhanced by the existence of a record below.

Fashioning a jurisdiction for the Court in cases of manifest urgency is an easier task. The Commission's Working Party recommended original jurisdiction over direct actions where "a rapid judgment is essential to avoid serious problems in the proper functioning of the Community institutions." ${ }^{74}$ The examples cited include actions for annulment of acts adopting the Community budget, suspending member state rights, and authorizing "closer co-operation" 75 among certain member states. Allowing direct access to the Court guarantees an expeditious resolution in these exceptional cases. In the United States, proceedings can be expedited through all levels of the federal courts in a matter of days. In contrast, the current translation requirements and the convening of large plenary sessions reduce the pace of emergency proceedings in the Court of Justice.

3. Appeals. The Treaty of Nice is conspicuously silent on the subject of appeals from the CFI's decisions on direct actions, ${ }^{76}$ so one can assume that the current system, whereby the parties and privileged interveners are automatically entitled to appeal on points of law, will continue unchanged, for the time being at least. Presumably, the declaration attached to the Treaty concerning the division of competence between the two Courts will be read as an invitation for the Court of Justice and the Commission to include recommendations for limiting appeals.

One promising idea, sadly overlooked at IGC 2000, is the introduction of discretionary jurisdiction for the Court of Justice, along the lines of the U.S. Supreme Court's certiorari jurisdiction. ${ }^{77}$ A European certiorari could target all decisions of the CFI, whether in the context of direct actions, preliminary rulings, or appeals from judicial panels. It would enable the Court to hear any case of its choosing while prioritizing its agenda and maximizing the use of its time and resources. The prospect of an enhanced appellate jurisdiction suggests the desirability of some such method of case selection. From a pragmatic standpoint, a screening mechanism would ensure that the burden of the Court's cur-

73. For a different view, see Contribution from the French Delegation, supra note 46, at 12 . The French delegation, among others, defended the current division of proceedings between the Court and the CFI on grounds of simplicity and clarity.

74. DUE REPORT, supra note 45, at 25 .

75. See EU TREATY tit. VII.

76. Notwithstanding considerable debate on the issue at IGC 2000. See Friends of the Presidency Interim Report, supra note 51, at 9.

77. See Liz Heffernan, A Discretionary Jurisdiction for the European Court of Justice?, 34 IRISH JURIST n.s. 148 (1999). 
rent original jurisdiction does not resurface in appellate form. The Community should also consider limiting the right of privileged parties to lodge appeals. Currently, any member state or Community institution may appeal a decision of the CFI, even if it is not a party to the proceedings. In the case of the Commission, its function as "guardian of the EC and EU Treaties" justifies the role; the Solicitor General performs a similar function in the United States. While it is appropriate that the member states and the other institutions retain the right to intervene in proceedings before the CFI and the Court, it is questionable whether they should enjoy the right to appeal a decision not so appealed by the parties.

\section{Judicial Panels}

The most innovative change to the current system is the introduction of a new form of judicial institution, the specialized judicial panel. Under a new provision, Article 225a, the Council "may create judicial panels to hear and determine at first instance certain classes of actions or proceedings brought in specific areas." The judicial panels will be attached to the CFI. Their jurisdiction and modus operandi will be determined at a later date by a decision of the Council.

1. Context. The concept of specialized judicial panels was inspired in part by the burden of staff cases-claims against the Community qua employerwhich have dogged case management in Luxembourg from the outset. In a declaration attached to the Treaty of Nice, the member states called on the Council to set up a judicial panel for staff cases as soon as possible. ${ }^{79}$ The field of Community employment is particularly amenable to specialized institutions and procedures. Composed of lawyers and assessors, the proposed panel will likely function in the same manner as administrative law judges in the United States, although its powers may also extend to conciliation. ${ }^{80}$ Another likely candidate for a judicial panel is trademark cases, currently adjudicated by the Alicante Boards of Appeals established under the Community Trademark Regulation. ${ }^{81}$ The possibility of creating a judicial panel for cases relating to the Community patent has also been mooted. Looking to the future, judicial panels would complement future independent Community agencies in scientific and technical fields such as air and maritime safety and food safety.

78. See EC TREATY art. 211 (formerly art. 155).

79. Declaration on Article 225, supra note 72.

80. See COURTS' DisCUSSION PAPER, supra note 40, at 16 (proposing the creation of a judicial panel for staff cases).

81. See Trademark Regulation, supra note 14. Applications for registration of marks are filed with the Office for Harmonisation in the Internal Market (OHIM) in Alicante, Spain. Currently, the decisions of the OHIM may be appealed to the OHIM Board of Appeals and from there to the CFI and on to the Court of Justice. Affording the OHIM Board of Appeals the status of a judicial panel would be a logical step. Its decisions could be appealed to the CFI and, in turn, only exceptionally, to the Court of Justice. 
Specialization within the judicial system is an attractive development and one familiar to continental European lawyers. Specialization, however, should not be given free rein. Most cases are not amenable to simple categorization, and it may be naïve to assume that the factors that lend staff and intellectual property cases to specialized treatment apply to other, more wide-ranging areas of Community law. ${ }^{82}$

2. Appeals. Judicial panels will be a welcome complement to the extended role of the CFI over direct actions and hold the promise of significant caseload relief in areas that are a particular drain on judicial resources. The efficacy of this reform, however, will depend in large measure on appellate procedures. Article 225a states that "decisions given by judicial panels may be subject to a right of appeal on points of law only, or, when provided for in the decision establishing the panel, a right of appeal also on matters of fact, before the Court of First Instance." ${ }^{83}$ This wording is somewhat ambiguous; it is not clear whether the Council, in establishing a panel, may opt to limit appeals altogether, for example, through a filer or leave-to-appeal mechanism.

Further uncertainty surrounds the possibility of subsequent review by the Court of Justice. The new version of Article 225(2) provides that decisions by the CFI on appeal from judicial panels may "exceptionally" be subject to review by the Court "where there is a serious risk of the unity or consistency of Community law being affected." The First Advocate General makes an assessment of whether there is a serious risk to the unity or consistency of Community law. If, in her view, the risk exists, the First Advocate General proposes that the Court review the CFI's decision. Thus, under the new regime, the First Advocate General will have a decisive gatekeeping role; cases will not reach the Court without her approval. Where the First Advocate General does make a proposal, the ultimate decision in favor of or against review lies with the Court. ${ }^{84}$

The same procedure will apply to the review of the CFI's decisions in response to preliminary references from national courts. Preliminary references, of course, are distinct from appeals, and are subject to their own special conditions. There, the intervention of the First Advocate General is in keeping with the practice of leaving the decision to seek Community review out of the hands of the parties. In conventional proceedings before judicial panels, party autonomy is the guiding principle. From the standpoint of the parties, however, appellate options end at the CFI. Whether a decision of the CFI is reviewed by the Court is a matter not for the parties, but for the First Advocate General,

82. The Commission's Working Party canvassed the possibility of specialized regimes for other fields, such as private international law, judicial cooperation in civil matters, and competition. While the Working Party might be faulted for embracing specialization with undue haste, the discussion provides a useful insight into the possible direction of future policy. See DUE REPORT, supra note 45, at 29-35.

83. EC TREATY art. 225 (formerly art. 168a).

84. STATUTE, supra note 16, as amended by the TREATY OF NICE, supra note 6, art. 62. 
and, ultimately, for the Court itself. The proposed limitation will have the benefit of forestalling lengthy appellate proceedings. It seems anomalous, however, that in a complex intellectual property case, to choose just one example, the parties should lose the opportunity to seek review by the Court itself. That the First Advocate General should be the gatekeeper of the Court's appellate jurisdiction is a radical departure from the principle of party autonomy and places a uniquely judicial function in the hands of an official without ultimate decision making authority.

A better solution would be to accommodate appeals from decisions of judicial panels within a general filtering system (a European certiorari), enabling the Court to decide which cases to review. In such a scheme, it would be possible to sidestep the CFI altogether and provide for a single appellate route directly to the Court. The proposed judicial panels will be "attached" to the CFI and presumably will operate under the CFI's general supervision, tracking its practice and procedures. Thus, it will be more economical to supervise the decisions of judicial panels in the same way as decisions of the CFI itself. In both instances, a filtering mechanism would be an attractive option. Appeals would be filed at the Court, which would be free to accept or decline them. Where the Court declined jurisdiction, the decision below-whether of the CFI, or of a judicial panel-would be deemed final. In contrast, the regime projected by the Treaty of Nice involves three potential tiers of review-by a judicial panel, the CFI, and, ultimately, the Court. At the very least, these lengthy proceedings should be reserved for truly exceptional cases.

\section{E. Preliminary Rulings}

Appropriately enough, the preliminary reference procedure dominated negotiations on judicial reform at IGC 2000. Preliminary references occupy half of the Court's docket and, on average, proceedings take twenty-one months to complete. ${ }^{85}$ Even within this contracted time frame, the Court is in danger of delivering preliminary rulings with undue dispatch, placing in jeopardy the quality of judicial discourse, the integrity of the institution and, ultimately, the rule of law within the Community. The strategic importance of the procedure can scarcely be overstated. But if preliminary rulings are the key to reform, the results of IGC 2000 are disappointing. Given the range and depth of the various proposals mooted in advance of the Conference, the modesty of the projected changes is striking.

1. Transferring Jurisdiction to the CFI. The most significant step taken at Nice was to remove the exclusivity of the Court's jurisdiction. Under the new Article 225(3), the CFI "shall have jurisdiction to hear and determine questions referred for a preliminary ruling under Article 234, in specific areas laid down

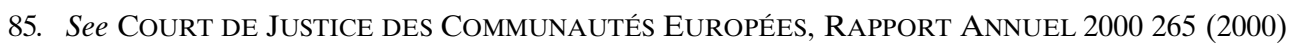
[hereinafter RAPPORT ANNUEL 2000]. 
by the Statute." The envisioned role for the CFI marks a profound shift in traditional thinking, which associated preliminary rulings with the Court's uniquely constitutional function. The Court itself had previously opposed the move, principally on the ground that it would threaten its special relationship with the national courts. ${ }^{86}$

It is too early to say whether the Treaty of Nice will lead to any demonstrable change in practice. It creates no more than a potential jurisdiction for the CFI; actual reform will have to follow later in the form of an amendment to the Statute, which will require a qualified majority vote by the Council. In the meantime, the issue should be included in the proposals on the division of competence between the Community courts, which the Treaty solicits from the Court of Justice, and the Commission. In short, the future of the preliminary reference procedure remains very much on the drawing board.

2. Defining the CFI's Jurisdiction. Assuming the CFI is conferred with de facto competence to deliver preliminary rulings, there is every reason to believe that its contribution will be limited, at least initially. For one thing, there are limits to the CFI's functional capacity. Its overburdened docket will expand with additional responsibilities over direct actions and appeals from judicial panels. The CFI cannot assume the burden of a substantial preliminary reference jurisdiction without a significant increase in its judges and resources. The larger the CFI becomes, however, the more pressing the question of the consistency of its judgments. Because preliminary references are procedurally more akin to certification than appeal, legislating for appellate review, which safeguards against the vagaries of adjudication by chambers or a single judge, is precarious. This environment is hardly likely to inspire the Court of Justice, and ultimately the Council, to delegate measurable control over preliminary rulings.

Even if the Court were willing, and the CFI truly able, to share responsibility for preliminary rulings, serious questions remain. Staking out a distinct jurisdiction for the CFI is a testing puzzle. Article 235(3) speaks of the CFI's jurisdiction in terms of "specific areas laid down in the Statute," which suggests a substantive definition. ${ }^{87}$ The specific areas might include the more technical fields, such as competition, that the CFI currently tackles under the rubric of direct actions. They might also extend to the specialized fields that will comprise its appellate jurisdiction over judicial panels. For example, since the CFI hears appeals on the subject of trademark registration from the Alicante Boards of

86. More recently, the Court has somewhat tempered its view. See COURTS' DisCUSSION PAPER, supra note 40 , at 25-26 (noting its previous objections but suggesting that the idea should not be dismissed out of hand).

87. See Meij, supra note 70, at 1043 (arguing, in advance of the Treaty of Nice, that "a priori regulatory definition of determined areas of jurisdiction (blocs de competence) designated for transfer is inevitable," and suggesting the field of intellectual property as a start). 
Appeals, it would make sense to assign it jurisdiction over preliminary references concerning trademark infringement. ${ }^{88}$

At first blush, assigning preliminary references to the CFI through a system of subject matter categorization has the merit of simplicity. Defining jurisdiction based on subject labels, however, can prove arbitrary and subjective. For example, it would be difficult to devise a clear delineation of competence over hybrid requests, involving two or more subject areas. In addition, subject matter categorization could subvert the natural judicial hierarchy. The bulk of preliminary references are relatively mundane and could safely be tackled by the CFI. But an issue of primary importance-ideally destined for the Court-may lurk in a case of any stripe or hue. The real challenge is to devise an effective and efficient means of delegating the more routine requests for preliminary rulings to the CFI while retaining the great controversies for the Court.

One possible solution is to identify the cases of primary importance up front, at the time of filing, and assign them directly to the Court. An allembracing formula might be devised, encapsulating the stated principle that cases of primary importance should go to the Court, and cases of secondary importance to the CFI. Judge John Cooke of the CFI has offered an interesting suggestion, grounded in Article 234's distinction between references from lower national courts and those from national courts of last resort: Give the CFI jurisdiction over the former and the Court jurisdiction over the latter. ${ }^{89}$ The supposition that national courts of last resort are more likely to generate the more important cases, though hardly watertight, seems instinctively sound.

However promising in theory, the answer has proven elusive in practice. Some such structural allocation may be as close as the Community can get to a workable formula of general application. In truth, notwithstanding certain objective criteria- the identity of the parties, the subject matter, a threat to consistency-there is no uniform understanding of what renders a case important. This is the thinking behind the U.S. Supreme Court's certiorari jurisdiction. The same basic premise should apply in the Community: If the decision is inherently subjective, it should be the Court's to make.

An alternative and more pragmatic route to the same result would be the introduction of a centralized system for the allocation of preliminary references. All requests for preliminary rulings would be filed at the Court of Justice and subjected to an expedited screening process. The Court would allocate the requests on a case-by-case basis, retaining for itself the cases it considers of primary importance and referring all others to the CFI. ${ }^{90}$ The system would resemble certiorari in terms of procedural mechanics, but it would not operate as 32.

88. A suggestion made by the Commission's Working Party. See DUE REPORT, supra note 45, at

89. See Cooke, supra note 41 , at 18.

90. See Costello, supra note 43 , at 53 (defending this approach against the objection that ad hoc allocation may offend the principle of juge legal or gesetzlicher richter, whereby the judge in a particular case must be preordained in advance by law). 
a filter. Recall that the preliminary reference jurisdiction is mandatory: The Court rules on the merits of all preliminary references except for a very narrow band that are deemed inadmissible, for example, because the answer to the question is nose-on-the-face plain. This practice would remain unchanged. Assuming that a national court request crossed the current admissibility threshold, it would lead to a preliminary ruling, whether from the Court or the CFI.

There are drawbacks to this approach. Upfront allocation might increase the margin of error: The importance of a case may be difficult to gauge from the face of the national court reference and may not become apparent until later in the proceedings. The real rub, of course, would be the time frame for the screening process. In this regard, the additional time required to allocate preliminary references would have to be weighed against the overall savings in time that a more efficient system would produce. For example, if the burden of preliminary references were shared with the CFI, the Court could rule on the merits of those references it did accept with greater speed. Above all, an allocation system would rule out a two-tiered review of preliminary references in Luxembourg - the Court reviewing the decisions of the CFI in response to national court requests.

3. Supervision by the Court. Regardless of how cases reach the CFI or, indeed, how many cases, it will be important to determine the circumstances in which they progress to the Court. The issue of supervising the CFI's jurisdiction over preliminary references is framed by competing concerns: the need to preserve a role for the Court versus the need to reduce the length of proceedings. The Treaty of Nice confronts the issue in two ways.

First, under the new version of Article 225, the CFI may refer a case to the Court for a ruling when the CFI considers that the case requires "a decision of principle likely to affect the unity or consistency of Community law." "91 This preview mechanism is reminiscent of the proposal for a system of allocating preliminary references, just discussed, with two important distinctions. The preview mechanism is intended as an exceptional safeguard rather than a routine allocation procedure. In addition, the screening function will be conducted by the CFI rather than the Court. Second, in exceptional circumstances, "where there is a serious risk of the unity or consistency of Community law being affected," a decision of the CFI in response to a preliminary reference may be reviewed by the Court, under the same conditions as a decision of the CFI in response to an appeal from a judicial panel. The assessment that such a risk exists will be made by the First Advocate General within a month of the CFI's decision; within a further month, the Court will determine whether or not the decision will be reviewed. ${ }^{22}$ Thus, here also, the parties lack standing to challenge

91. This provision was influenced, in particular, by a proposal from the Dutch Government. See Contribution from the Dutch Government, supra note 53, at 15.

92. See STATUTE, supra note 16, as amended by the TREATY OF NICE, supra note 6, art. 62 . 
the CFI's ruling before the Court. ${ }^{93}$ In a declaration attached to the Treaty of Nice, the Conference expressed the view that, when the Court of Justice reviews a CFI decision in response to a preliminary reference, it should act under an emergency procedure. ${ }^{94}$

These preview and review mechanisms share similar flaws. The initial decision whether the Court of Justice should decide a case is essentially subjective, ${ }^{95}$ and it is made by an entity other than the Court itself. In effect, the CFI and the First Advocate General will be gatekeepers of the Court's jurisdiction. It is highly unusual in modern legal systems that a court should lack control over its own jurisdiction. In this instance, it is all the more anomalous that the jurisdictional determination should be made by a subordinate court (the CFI) or an officer that lacks ultimate judicial decision-making authority (the First Advocate General). ${ }^{96}$ Leaving the decision in the hands of the CFI and the First Advocate General could in its own way threaten the uniformity, consistency, and, indeed, the objectivity of Community law. A further and more adverse concern is that referral to the Court will become less than exceptional and will increase the cost and length of proceedings. It will be important to ensure that the participation of the CFI does not simply add an additional tier of review, all the more so since the preliminary reference procedure stays national court proceedings.

The headaches do not necessarily end there. For example, when the CFI has delivered a preliminary ruling in response to a request from a lower national court, would it be possible for a national supreme court to effectively appeal the CFI's ruling by seeking a preliminary ruling from the Court itself? Recall that the Treaty obliges a national court of last resort to seek a ruling from the Court on a point of Community law that is central to the resolution of the national proceedings. Thus, for example, a lower national court could obtain a preliminary ruling from the CFI and apply it in order to decide the case; on appeal, the Community law issue could be raised anew and referred to the Court of Justice by the national supreme court. However unlikely, the timing and expense of two preliminary references during the course of the same proceedings scarcely bears contemplating. Thus, the finality of the CFI's decision will be crucial, not merely as a matter of form. The success of the enterprise will turn on the CFI's ability to exercise a firm and decisive hand in responding to national court requests.

4. The National Courts. Regrettably, the Treaty of Nice makes no attempt to reduce the volume of requests for preliminary rulings emanating from the na-

93. A change recommended by the CCBE. See Contribution from the CCBE, supra note 47, at 9.

94. See Declaration on Article 225, supra note 72, at (2) and (3).

95. The First Advocate General, at least, will have the benefit of the CFI's decision on which to base her assessment of a serious risk to the unity or consistency of Community law.

96. Indeed, there is an inherent contradiction between the Conference's willingness to attribute this authority to the First Advocate General and its refusal to count advocates general in the judicial tally for the composition of the Court. 
tional courts. Notwithstanding the many and varied proposals of the Commission's Working Group and others, the Conference decided against altering the mechanics of the procedure. Thus, the role of the national courts and the terms and conditions under which cases are currently referred will remain unchanged. ${ }^{97}$ Retention of the status quo will assuage the concerns of many anxious to preserve automatic access to justice in Luxembourg, but it will not lead to any significant reduction in the length of proceedings. For the time being, one can assume that preliminary references will continue to be an enormous drain on resources at the Court of Justice.

III

\section{CONCLUDING REMARKS}

The Treaty of Nice does not alter the essential structure of the judicial system, comprised of the Court of Justice, the Court of First Instance, and the national courts of the member states. It does, however, presage two related, structural developments: increased responsibility for the CFI and the creation of specialized judicial panels. Both initiatives are welcome. Indeed, the shift in emphasis in favor of the CFI is one of the Treaty's most significant and attractive features. Potentially, the CFI will become the primary forum for direct actions, a secondary forum for preliminary references, and an appellate forum for decision from judicial panels. The CFI will no longer be simply "attached" to the Court ${ }^{98}$ rather, ensuring that the law is observed will be the task of both courts, each within its own jurisdiction. At the same time, the Treaty incorporates certain safeguards to ensure that the Court of Justice has the final say on the interpretation of Community law.

Under the new regime, there will be no other species of Community court, at least for the time being. In contrast to the U.S. system, the E.U. system will not have Community trial courts located in the member states or intermediary E.U. courts, whether defined by territorial or subject-matter jurisdiction. ${ }^{99}$ On this score, the Conference acted wisely. The conditions that led the U.S. Congress to establish federal district courts and, subsequently, courts of appeals, generally do not apply to the European Union today. The specter of bias in national court proceedings is less of a concern in these modern, transitory times. The national courts are constrained by the preliminary reference procedure and their inability to strike down Community laws. While the Community has sowed the seeds of a binding bill of rights, it lacks a substantive criminal jurisdiction.

97. See Meij, supra note 70, at 1043 (noting that the national courts were not associated with the reform negotiations in any way).

98. EC TREATY art. 220 (formerly art. 164).

99. See COURTS' Discussion PAPER, supra note 40, at 26-27. See generally Jacques \& Weiler, supra note 43; SLYNN REPORT, supra note 43. 
Moreover, there are persuasive grounds against limiting the national courts' Community functions. The various Community courts would function using different languages and in cultures more diverse than those that span the federal districts in the United States. The system would be duplicative and could threaten the stature of the national court as the doorway through which individuals access the Community system. In the United States, mixed cases routinely appear on both sides of the haphazard line dividing state and federal jurisdiction. Whereas federal adjudication of state questions can be controversial, a corresponding jurisdiction for the Community courts over national law would be an unthinkable affront to a still jealously guarded sovereignty. Even the Court of Justice, which has the power to condemn and penalize an errant member state, lacks the authority to review national legislation or overturn national judgments. Thus, the most that a lower Community court could do is perform the functions currently entrusted to the CFI but with a greater geographical, but not necessarily ideological, proximity to the populace.

If the CFI needs structural support, the specialized judicial panels envisioned by the Treaty of Nice are a superior model. Their specialized mandate will target areas of Community practice that are particularly labor-intensive or that otherwise warrant special treatment. Attached to the CFI, the judicial panels can be incorporated within an existing infrastructure, and, given their limited mandate and structural location, they are less likely to stray from the direction of the CFI and Court of Justice. These considerations do not alter the conclusion that the use of judicial panels should be reserved for a limited number of select areas conducive to specialization. Certainly, the CFI should guard against a gradual dismantling of its jurisdiction through the expedient of judicial panels.

The problem with the Treaty of Nice, then, is not the emphasis on the CFI, nor the addition of judicial panels per se. Rather, the Conference's legacy turns on the questionable assumption that modifying the role of the CFI will cure the ills of the entire system. Thus, quantitative change at the CFI is designed to produce a qualitative change at the Court of Justice. If the center of gravity-at least in terms of caseload-is moved to the CFI, the Court of Justice will be in a better position to pursue its constitutional mandate, or so the thinking goes. In effect, the Court will carry out the same essential functions but, it is hoped, in a more select fashion.

The promise will hold true, if at all, only if two conditions are met: 1) the transfer of jurisdiction from the Court to the CFI must be real and substantial; and 2) the CFI must be provided with adequate financial and administrative resources to equip it for the task. The fulfillment of either condition does not seem fanciful when applied to direct actions. The Council could make the CFI the de facto first judicial forum for direct actions and, presumably, marshal the necessary resources. Direct actions, however, account for far less of the judicial 
workload than do preliminary references. ${ }^{100}$ Moreover, gains for the Court must be counterbalanced against a projected increase in appeals. ${ }^{101}$

The fallacy of the Conference's reform strategy is revealed in its treatment of preliminary references. The Conference seized on the CFI as the key to reducing the length of "Community law proceedings"102 in national courts by speeding up the preliminary reference procedure in Luxembourg. In fact, it is unlikely that the CFI has the capacity and resources to shoulder this burden effectively, given the totality of its responsibilities. The net result is no meaningful relief for the Court from the strain of preliminary references. The Conference made no effort to attack the problem at its source, namely, by taking steps to stem the flow of preliminary references from the national courts. Whatever the division of labor in Luxembourg, the national courts will continue to request countless preliminary rulings. This fundamental deficiency in the Treaty of Nice underscores a continuing need to discuss alternative reform measures in the aftermath of IGC 2000. If, as the Courts and the Commission's Working Group contend, the central objective is to render the legal system more efficient and to equip the Court of Justice to perform as a supreme court, the Treaty falls short of the mark. Its package of reforms will undoubtedly improve the system, but not to the extent necessary to remedy the workload crisis, much less prepare the courts for enlargement and, ultimately, for the defense of a bill of rights.

Several factors account for the Conference's conservatism: the limitations surrounding an intergovernmental conference, both practical and political; the caution of the contributors to the debate, including the courts themselves; and the complexity of the preliminary reference procedure. The Treaty of Nice is also symptomatic of certain flaws in the underlying debate about judicial reform. Notwithstanding the strong language in which the crisis is commonly cast, there is an overriding tendency to underestimate the extent of the problem. Thus, the typical discussion opens with a doomsday scenario and a call for radical action, but hesitates at the brink and settles on a compromise solution. For all the talk, and the invocation of architectural analogies, at the end of the day, few are willing to countenance radical reform.

Yet the crisis remains. There is consensus that the courts are working at the limits of their capacity in servicing the Community of fifteen member states at the present stage of European integration. The courts are not just stretched; they are so extended that the system can no longer be considered efficient or, more alarmingly, effective. Even if the Community remained static, both in terms of membership and competence, the judicial system would be ill-

100. For example, of the 503 cases filed at the Court in 2000, 197 were direct actions as opposed to 224 preliminary references. See RAPPORT ANNUEL 2000, supra note 85, at 265.

101. Appeals accounted for 79 of the 503 cases filed at the Court in 2000. See id.

102. Of course, they are not Community law proceedings in the strict sense but rather Community law questions that arise during the course of national proceedings. 
equipped to handle the growth in Community litigation that will arise in the ordinary way. Thus, far-reaching reform would be imperative even if the path of European integration were set in stone. In reality, of course, the Community's future is an open book: The membership will almost certainly increase by onequarter in the next five years and could double, not at some unforeseen distant time, but within thirty years, at the very least. ${ }^{103}$ With each enlargement, the Community will grow, not only in size, but also in diversity, lingually and culturally, and in complexity, with some states integrating more closely than others. ${ }^{104}$ As if all this were not challenge enough, we can expect the Community's substantive competence to extend further into the national domain. Today, a national court must stay proceedings for almost two years to facilitate a ruling from the Court of Justice. What can we expect in the future? Imagine the European Union twenty years hence, with a membership of twenty-five states, combining a population almost twice the size of the United States, sharing an internal market, a single currency, common policies in fields as diverse as foreign policy and crime, and a full-blown commitment to the protection of fundamental Community rights. Now imagine the needs of that European society in terms of the administration of justice. Finally, imagine the current judicial system striving to meet those needs. That is the challenge of reform.

The Community's response to the challenge is not altogether unreasonable. Instead of meeting the challenge in one fell swoop, IGC 2000 opted to start down the road to reform and, at the same time, give the system the necessary flexibility for the remainder of the journey. Thus, the Treaty of Nice is intended to mark the commencement or, more accurately, the continuation rather than the culmination of the reform process. As noted, several of its provisions lay the groundwork for future developments without necessarily committing the courts to their adoption. In this regard, the Community should have an eye to the next intergovernmental conference, scheduled for 2004. ${ }^{105}$ However, there are risks to "wait and see" as a reform philosophy. The crisis in the courts is too entrenched to permit a gradual, low-level recovery. It is hard to see how the courts will ever get ahead under this regime. More importantly, flexibility must be balanced against other core values in the legal system, such as legal certainty. The Community must ensure that reform does not become so piecemeal and protracted as to undermine the integrity of the rule of law. Constant, spasmodic change may also jeopardize the transparency and accessibility to which the system aspires. Finally, flexibility is a poor substitute for a lasting design of the judicial system. This is perhaps the greatest indictment of IGC 2000: It leaves no roadmap but only a sense of the general direction in which the courts are

103. Cooke, supra note 41 , at 14.

104. EC TREATY art. 11 (formerly art. 5a).

105. Judicial reform is not currently on the agenda for IGC 2004. However, one may assume that the pressure for reform generated at IGC 2000 will be maintained in the coming months and beyond. See Declaration on the Future of the Union (attached to the Treaty of Nice), 2001 O.J. (C 80) 85. 
headed. To put it another way, in focusing on the various parts, the Conference may have lost sight of the whole.

The reform debate has obscured two quiet but important facts. First, the transfer of jurisdiction to the CFI must be accompanied by a transfer of real decision-making authority. In other words, there must be a sense that the CFI's decisions are final as a general rule and, only occasionally, the subject of appellate review. The Conference has laid at least some of the groundwork for this decisive shift, but it remains to be seen whether the various actors-the Council in amending the Statute and Rules and the Courts in applying its imprimaturwill implement it in practice. Second, some decentralization of judicial responsibility is inevitable and even desirable. ${ }^{106}$ The demands of a fully enlarged Community will be too much for the Court and the CFI alone, even with the aid of judicial panels. The Community may create additional Community courts in time, but that could prove a mixed blessing, for reasons discussed above. A more sensible alternative is to delegate responsibility directly to the national Courts, thereby enhancing their Community law credentials. The steps that the Community might take to achieve this goal are beyond the scope of the present discussion. There is, however, ample scope to develop promising ideas for reform, including proposals that draw on U.S. experience, such as introducing a European certiorari, and limiting the power of lower national courts to refer cases directly to Luxembourg.

In summary, the Treaty of Nice signals an important step in the evolution of the Community's judicial system. Taken collectively, the reforms should go some way towards alleviating current pressures and preparing for future challenges. It is difficult, however, to predict the impact of many of the projected reforms; the devil will be in the details, many of which have yet to be decided. The starting point is clarification of the division of competence between the Court and the CFI. Legal issues aside, the success of the reforms is intrinsically linked to the provision of adequate financial and administrative resources, especially at the CFI.

For advocates of radical reform, the decision to renovate rather than redesign the judicial architecture is a disappointment. The package of reforms adopted at Nice is too modest, standing alone, to guarantee effective, lasting solutions to the present crisis, much less to equip the courts for future challenges, including the defense of a bill of rights. Only time will tell whether IGC 2000 has paved the way for the lasting administration of justice or condemned courts and litigants alike to continued gridlock. The pressure for further reform must be maintained. In particular, the Community should consider whether lessons may be learned from the structure and operation of the U.S. federal courts,

106. The proposed overhaul of the competition rules, which will involve a fundamental reorganization of existing responsibilities between the Commission, national competition authorities, and the national courts, points the way. See White Paper on Modernization of the Rules Implementing Articles 85 and 86 of the EC Treaty, 1999 O.J. (C 132) 1; Claus Dieter Ehlermann, The Modernization of EC Antitrust Policy: A Legal and Cultural Revolution, 37 COMM. MKT. L. REV. 537 (2000). 
particularly in its historically vibrant defense of civil rights. Efforts must be made to generate fundamental reflection and democratic debate on such important issues as the relationship between national and Community courts and the legitimate expectations of European citizens in the administration of justice. 